\title{
MEDIA TECHNOLOGIES IN TEACHING PHILOSOPHY
}

\author{
Elena Grednovskaya, Svetlana Reschikova, Kirill Rezvushkin \\ South Ural State University \\ Russia, Chelyabinsk, Lenin Avenue, 76 \\ phone: +79123063166, e-mail: pos0909@rambler.ru
}

\begin{abstract}
This article describes the experience of the Department of Philosophy of the South Ural State University (Russia) on the use of media technology in the teaching of philosophy. Media technologies are examined not simply as tools of knowledge translation to students, but they are comprehended as a media reality, which sometimes completely dissolve a human. Media philosophy which appeared as a new philosophical trend that meets the today realities, contemplates the nowadays situation of influence of mass communications on human's world outlook, on his selfidentification, also on his body and feelings. The students are possessed to analyze a visual media material, because the foundation of media reality is a visual image.

Key words: philosophy of education, media reality, media technology, media philosophy.
\end{abstract}

\section{INTRODUCTION}

The realities of the 21st century require new approaches of modern man to understand himself and his activities. Therefore, in our difficult existence as never thought required a strictness of thought, criticality, and creativity of each individual. These qualities can give philosophy. A year ago this idea is clearly voiced in the letter of the General Director of UNESCO Irina Bokova on the occasion of World Philosophy Day: "Philosophy can make an important contribution to human well-being, the decision facing him the most complicated issues and the strengthening of peace". According to Irina Bokova, the philosophy is "an instrument of personal and collective liberation" of man. "We have as high as possible to raise the philosophy flag, - she writes, - to attach to it all the women and men and, especially, all girls and boys". Thus, the teaching of philosophy nowadays is very important. Moreover, in order to attract the attention of a wide audience, especially young people, is not enough to use only traditional academic teaching methods, cutting-edge technologies are also necessary.

\section{METHODS}

It should be noted that the teaching of philosophy traditionally is a complex task, coupled with the overall number of objective phenomena, such as:

- The fundamental ideological basis, developed in the consciousness of the individual;

- Type of mentality of students, due to national peculiarities of representatives of different countries (for example, students from Iraq represents "Eastern philosophy" and/ or "religious philosophy, students from China - "Confucianism" and/or "Mao Zedong Thought ", etc.);

- The lack of a unified database of philosophical knowledge (for example, for Russian students the philosophy is a basic course, and in some countries this is the subject of selectable courses). 


\section{ARTTIE $Y$}

Ipplied Resseirlohes in Technics, Technologies and Bductation

Journal of the Faculty of Technics and Technologies, Trakia University https://sites.google.com/a/trakia-uni.bg/artte/

In last few years we have to add one more aspect for the complexity of educational practice in the field of philosophy. We are speaking about the of "media reality" describing the today's all-consuming and all-encompassing reality of technical intermediaries influencing the reality of experience and consciousness, which characterize a new stage of mankind development.

In addition in today's world the role of modern technology in the educational system grows incredibly. It is based on the media overcoming the boundaries and necessity of inclusion a modern student in multdisciplinarity, multitasking and modern learning.

However, many scientists think that the philosophical reflection on the actual processes considerably delayed.

In this situation it is understandable emergence of new philosophical and cultural disciplines - media philosophy where its subject is media reality, given new technologies, includes both human conditions, means, and ends communication.

Due to the fact that the foundation of media reality is a visual image that creates the image of the world that is indistinguishable from reality, we came to the conclusion that the time has come to study philosophy students include such forms of work, which is based on the visual media material. On the one hand, it is a direct, practical use during lessons diverse visual media material for discussion and understanding of its content, form and role in modern society. On the other hand, it is the very reflection on the modern medieval studies which is carried out in our university whole series of events.

Firstly, this is based on the philosophical club, working in our department, in which discussions are media philosophy goals and objectives, understanding of phenomena such as social networking, resource sites, and communities and so on. Secondly, it is a virtual scientific conferences and "round tables" in-line with the participation of undergraduate and graduate students. Thirdly, it is working on a new generation of textbooks, including the style of presentation of a block of information, visualization of theoretical material, introduction of electronic resources. Fourth, it cinema philosophical seminars, where the aim of the training course is the students' self-designation of the way through the philosophical understanding of educational and training practices of the future from the standpoint of philosophical-anthropological and socio-philosophical approaches;

Thus, we concluded that the integrity of philosophical knowledge can now be based only on the text of philosophical presentation material. Need navigation, giving the correct orientation in the media (network, electronic, web-resource, cinema, etc.). Hence, the most important component of the South Ural State University research project devoted to the Department of Philosophy postmodern forms of translation and representation of philosophical knowledge.

\section{EXPERIMENTAL PART}

During the year, we have formulated the concept and methodological foundations of activity Philosophy Club, where the subject of reflection of the participants is a postmodern phenomenon, designated "media reality" and reflection form, supporters of which are the organizers, representatives and members of the club at the moment is already formulated as media philosophy. It solves problems that previously belonged to the sphere of interests of the philosophy of science, culture, sociology, political science, aesthetics and theory of art, from the perspective of the impact of the results of high-tech person. In other words, she thinks the situation of human exposure, on his view of the world outlook, the identification method on his body and feelings of mass communications; it sharpens the issue as possible in the situation of human existence ever-increasing stream of tempting, addicting and, inevitably, dissolving it in himself media reality. Media philosophy inevitable as well as in their time were unavoidable metaphysics, epistemology, philosophy of science and technology,

IRTIIE Vol. 4, No. 3, 2016 ISSN 1314-8788 (print), ISSN 1314-8796 (online), doi: 10.15547/artte.2016.03.010 


\section{ARTTIE $Y$}

Ipplied Researthes in Teednics, Teechnologies and Riduration

Journal of the Faculty of Technics and Technologies, Trakia University https://sites.google.com/a/trakia-uni.bg/artte/

philosophy, art, politics and law. It - an adequate and timely response to the challenges of modernity. A significant reason for turning to media philosophy is that traditional aesthetics expressed evaluative attitude to reality, but with regard to these forms of medial radio, Xrays, cinema photography, computer games, pop-scene, contemporary art, author videos, etc. It took a new means of analysis applicable to all the phenomena that are not grasped network aesthetic categories (Lambert Wiesing). Media philosophy analyzes the role of a media: a condition of its emergence, operation methods, distribution, and does not evaluate in the evaluation categories.

Basic media reality - visual image because the visual images create an image of the world, indistinguishable from reality. That is why the basis of analysis of the current material of our club is taken, first of all, visual media materials (videos, movies, video games, videos, screenshots, etc.). All this was reflected in the themes of the meeting of our club. For example, discussing the theme "Man in the fetters of social networks," the club members compared the different communities, isolated by their subjects, especially discussed the interaction space within the community and beyond its borders, trying to figure out the effects of their influence on the formation of the identity of the person. Of great interest the club's members caused a theme "YouTube phenomenon as a mirror of post-humanity". Discussion of this phenomenon was reduced to its different aspects: Video examinations like existence in video documental reflexing of everyday life, as a space for creative expression and cultural reflection, philosophical freedom of expression. In this academic year the club members, who include both students and teachers, and invited scientists from other Russian cities, continue their work. They discuss topics such as "normative core" media philosophizing", "Marginalia media philosophizing".

Another form of work are virtual conferences online that are attended by faculty and graduate students of our university, educational institutions of the city of Chelyabinsk and other Russian cities, as well as our foreign colleagues. A feature of this conference is that many participants do not leave the walls of their schools, and even homes, while being active participants in it. It does not require leave the work for a few days, the financial cost of the trip, allows you to feel with the maximum comfort. In April 2016 the Department of Philosophy of the South Ural State University in cooperation with the Department of Philosophy and Cultural Studies of the Chelyabinsk State Pedagogical University, carried out a joint project of the virtual round tables within the framework of the scientific-practical conference "The philosophical practice in the modern university: problems and forms of organization of philosophicalpartnership." The online discussion materials connected with the most interesting, non-standard approaches philosophical practice and possibilities of their use in the teaching of philosophy. Great interest was aroused discussion:

- What is philosophical practice?

- How to organize a philosophical partnership?

- How to reconcile with the interlocutor's own speech (the Socratic dialogue)?

- What is philosophy for children?

Along with professors and graduate students from Chelyabinsk these issues actively discussed the scientists of Moscow, Volgograd and other cities of Russia. Successful experience in the use of Internet capabilities in scientific conferences has led us to believe that virtually all research activities can and should be carried out in this format. Then, firstly, to the participants of these events will not be restrictions neither in space nor in time, and secondly, Internet technologies enable the presence of participants with a maximum for yourself the comfort that removes moment of excitement or a lack of material "at hand" and etc.

In our opinion, another important form of work devoted to postmodern forms of translation and representation of philosophical knowledge was the work of a new generation of textbooks, this textbook on the philosophy that students would not be frightened of the

IRTIIE Vol. 4, No. 3, 2016 ISSN 1314-8788 (print), ISSN 1314-8796 (online), doi: 10.15547/artte.2016.03.010 


\section{ART'TE $Y$}

Ipplied Researthes in Technics, Technologies and Bdurition

Journal of the Faculty of Technics and Technologies, Trakia University https://sites.google.com/a/trakia-uni.bg/artte/

infinitely complex articles and adequately fit in the interests of their media reality. After analyzing numerous textbooks and manuals on the philosophy of Russian and foreign authors, we came to the conclusion that the hallmarks of modern textbook for students should be a block style of the information (including neurophysiologic aspects of perception of today's college students, blocks of text may not exceed 15-20 lines) illustrate the theoretical material with examples from praxis (philosophy of life); Visualization of theoretical material when referring to culturological formation (reproduction, examples from literature, movies, etc.). But that is still very important, in our opinion, due to the prevalence in modern students' visual perception of the type and strength of their proximity to the Internet; in the textbook should be an indication of the broad representation of the philosophical content on the Internet, familiarity with electronic resources for philosophy. We believe that it is this tutorial will focus on the younger generation.

Philosophical cinema seminary is one of the most traditional forms of work in our department. Discussion of films and movies allows students to identify the visual artistic images with their worldview. Since this form of training is their special interest, from the scattered workshops we aim to move to a separate cycles united by one theme. So, in the spring was a cycle of seminars on the theme "Dialogues of the four anti-utopias". This cycle has been presented to view 4 cinematic dystopia and their subsequent discussion in outline certain conceptual ideas interdisciplinary format. Kinoseminarov authors sought to identify the problems of the modern Russian education by a philosophical understanding of the ideas expressed in science fiction movies, as well as to identify the means of education and training of modern man conducive to understanding its place and prospects in the education system.

\section{RESULTS}

Using media technology has allowed drawing students' attention to the philosophy, despite the fact that its study, as mentioned earlier, causes certain difficulties. To date, members of the philosophical club are students of the University for the different faculties, both humanitarian and technical. Moreover, they are not passive listeners, along with teachers and organizers of the club are actively involved in research related to the problems of the issues discussed.

About markedly increase the interest in the philosophy of evidence and scientific-practical conference of students, the number of participant's increases each year. So, in 2015 in a student conference was attended by 35 students from different faculties and courses in the current academic year, there were already 55. The next step-a student's Internet conference, which will involve the participation of a large number of students, not only of our university but also from other universities.

As Mahatma Gandhi said, "our whole philosophy is as dry as dust, if not immediately convert it into some live acts of service." One of the directions of research work of the department was the further development of philosophical practice. Almost all the teachers of the department have been trained "Theory and practice of philosophical counseling", three young teachers took part in an international seminar on the philosophical practice of Oscar Brenif'e held in August this year in France. Thus, the staff of the department has a comprehensive joint research activities (at the junction of several fields - philosophy of science, technology, philosophy, philosophical anthropology and philosophy of education), dedicated to the analysis of the translation of philosophical knowledge in postmodern cultural space based on the latest modern media technologies, taking into account the effects that they generate. 


\section{IPITIP Journal of the Faculty of Technics and Technologies, Trakia University https://sites.google.com/a/trakia-uni.bg/artte/}

\section{CONCLUSIONS}

The radically of the innovations of the XXI century has equally radical transformation of philosophical instruments, methodological approaches. Media philosophy inevitable as well as in their time were unavoidable metaphysics, epistemology, philosophy of science and technology, philosophy, art, politics and law. It is an adequate and timely response to the challenges, as sharpens the issue as possible in the situation of human existence everincreasing stream of tempting, addicting and, inevitably, dissolving it in himself media reality. Thanks to her, the technology "tightening" the consciousness of modern man into a virtual web of web-worlds, in this case operate unconditionally positive role, forming an information space inter paradigmatic connections printed and web-resource measurements that correlate philosophical, scientific and educational patterns of modern subjects of knowledge.

\section{LITERATURE}

[1] Savchuk V V. On the subject mediaphilosophy. http://mediaphilosophy.ru/biblioteca/books/mediaphilosophy_1/.

[2] Savchuk V. V. Inevitability mediaphilosophy. http://mediaphilosophy.ru/biblioteca/articles/savchuk_inevitability/.

[3] Modern trends in media. https://vernsky.ru/pubs/5250/SOVREMENNYE_TENDENTSII_RAZVITIYA_MEDIA_V KONTEKSTE_KONTSEPTSIY_TORONTSKŌY_SHKOLY_T̄.

[4] Mediafiliosofiya. Key issues and concepts: materials of an international conference. http://www.intelros.ru/intelros/biblio_intelros/2974-mediafilosofija.-osnovnyeproblemy-i.html 